Yayın Geliş Tarihi: 08.12.2014

Yayına Kabul Tarihi: 03.03.2015

Online Yayın Tarihi: 31.08.2015

http://dx.doi.org/10.16953/deusbed.72942
Dokuz Eylül Üniversitesi

Sosyal Bilimler Enstitüsü Dergisi

Cilt: 17, Say1: 1, Y11: 2015, Sayfa: 33-52

ISSN: 1302-3284 E-ISSN: 1308-0911

\title{
ACCESS TO THE EU LABOUR MARKET FOR THE THIRD COUNTRY NATIONALS: THE CASE OF FREE MOVEMENT OF THE WORKERS BETWEEN TURKEY AND THE EU
}

\begin{abstract}
The decreasing demography and visible deficit of labour force raise a question of the future steps taken by the EU and its Member States to solve these problems affecting the economy of the whole Europe. Although much attention is paid to recently established instruments of the EU immigration policy with the aim to attract workers from Third States, the attempts to facilitate an access to internal market by Turkish nationals should be particularly considered. The constantly increasing role of the Republic of Turkey as a regional power stabilising the Balkans and Middle East puts the EU under political pressure, forcing the Member States to take a final decision on Turkey's place in the European economy and the legal status of Turkish labour within freedoms offered within the internal Market. This paper aims to examine the legal framework and main principles governing the free movement of Turkish workers in the EU. It identifies the EU-Turkish relations from the perspective of individuals searching an access to European labour market with particular emphasis on their rights arising from the so called association law and formal obstacles that Turkish workers encounter when exercising these rights.
\end{abstract}

Maciej CESARZ*

Keywords: Association Law, Free Movement of the Workers in the EU, Turkish Workers, EU Visa Policy.

\section{ÜÇÜNCÜ ÜLKE VATANDAŞLARININ AB İŞGÜCÜ PIYYASASINA ERIŞ̧IMİ: TÜRKIYYE VE AB ARASINDA İŞÇILERİN SERBEST DOLAŞIMI ÖRNEĞİ}

$\ddot{O} z$

Azalan nüfus ve gözle görülür işgücü açı̆̆g gibi bütün Avrupa ekonomisini etkileyen sorunlar, $A B$ ve üye ülkeler tarafindan bu sorunları çözmeye yönelik yakın gelecekte atılacak adımlar konusundaki tartışmaları gündeme getirmiş̧tir. AB göç politikasının üçüncü ülkelerden gelen çalışanları cezbeden yeni araçları dikkate değer olmakla birlikte, Türk vatandaşlarının tek pazara ulaşımını kolaylaştıran girişimlerin özel olarak değerlendirilmesi gerekmektedir. Balkanlarl ve Ortadoğu'yu dengeleyen bölgesel bir güç olarak Türkiye Cumhuriyeti'nin giderek artan önemi, AB'yi siyasi bask altına almakta, Türkiye'nin Avrupa ekonomisindeki yeri ve Türk işgücünün iç pazar ile sağlanan özgürlükler dahilindeki yasal statüsü hakkında üye ülkeleri nihai bir karar almaya zorlamaktadır. Bu makale Türk çalışanların AB'deki serbest dolaşımını düzenleyen yasal çerçeveyi ve temel ilkeleri ortaya koymayı amaçlamakta ve AB-Türkiye ilişkilerini Avrupa

\footnotetext{
* Dr., University of Wrocław, Chair of the European Studies, maciej.cesarz@uni.wroc.pl
} 
işgücü piyasasına kişilerin erişiminde söz konusu ortaklık hukukundan doğan hakları ve Türk işçilerin bu haklar uygulanırken karşılaş̧tı̆̆ yasal engeller bağlaminda tanımlamaktadır.

Anahtar kelimeler: Ortaklık Hukuku, AB'de İş̧̧ilerin Serbest Dolaşımı, Türk Isşcileri, AB Vize Politikası.

\section{AIM AND STRUCTURE}

This paper aims to analyse the legal framework and main principles governing the free movement of Turkish workers in the EU. For this purpose it is divided into the two parts; first one investigates the EU-Turkish relations in the view of persons searching an access to European internal market and contains a general study of the so called association law, covering the status of Turkish nationals, who would like to enjoy free movement of labour in the EU Member States. The question of the status of Turkish labour as particular category of Third Country Nationals (TCNs) on the internal market is addressed in few steps. Firstly, the article investigates the historic background and motives that have driven the Communities to facilitate admission of Turkish labour force through Ankara Agreement and other documents. This includes a brief description of the so called association law established between Communities/EU and the Republic of Turkey. The binding force and place of this set of rules in the framework of the acquis communautaire is examined in the next section. To prepare the ground for a more detailed analysis, the third section outlines the most relevant secondary law of the EU referring to the subject of the paper, including decisions of the Association Council, which are brought as a basic legislative context. Fourthly, the definition of Turkish workers and their primary rights are shortly presented with reference to most relevant case law produced by the Court of Justice of the EU (CJEU). The fourth section brings a short comparison between the status of Turkish labour and EU citizens enjoying their rights as migrant workers.

In the second part of the article EU visa policy towards Turkish citizens is examined, as it is major formal obstacle for Turks seeking to enter the territory of the EU and join European labour market. The short background of EU-Turkey visa relations is outlined, including the presentation of the main regulations covering non-EU nationals trying to cross external border of the Union. The analysis is placed within the context of current EU-Turkey visa dialogue, with reference to established by both counterparts visa roadmap and readmission agreement. While citizens of the Western Balkan states already enjoy visa-free travel to EU Member States, Turkey, in contrast, was only offered a vague promise for the initiation of a visa liberalisation "dialogue" in return for initialling the readmission agreement (Baysan, 2013: 740).

It should be highlighted however that the scope of analysis is limited to Turkish individuals crossing border with the purpose to enjoy free movement of the workers, with reference to other freedoms of the internal market (particularly 
services) only when necessary. The main research may be thus summarised to following questions:

1) What are the most relevant legal documents covering the rights of Turkish citizens who want to enter the EU and enjoy free of movement of the workers?

2) What kind of rights they enjoy on the basis of the current acquis?

3) What is the main formal obstacle for Turkish nationals, when they attempt to enjoy the rights conferred upon them?

In the last section a conclusion is given with reference to the previous findings in order to provide an answer to the research questions.

\section{BACKGROUND AND MOTIVES OF THE ADMISSION OF TURKISH WORKERS TO THE INTERNAL MARKET.}

The official relations between the Communities and the Republic of Turkey are dating back to 1963, when the Agreement establishing association between European Economic Community and Turkey was signed (Ankara Agreement - AA). While previous Turkey's application of membership to the European Community (submitted in 1959) was approached with caution, Ankara Agreement established a long-awaited, interim compromise. The document confirmed the will of the parties to enhance cooperation in economic dimension and was agreed with the aim of wider Turkish participation in the European integration process. This aim was to be achieved by promoting balanced and continuous strengthening of trade and economic relations between the parties (AA, art.2), including the free circulation of workers, establishment and services and harmonisation with EEC policies relating to the internal market. The Treaty provided for three periods, comprising preparatory stage followed by transitional and final stages, through which association between the EEC and Turkey would proceed, finally clearing the path towards Customs Union and eventually the free movement of the labour (Çiçekli, 2004). According to art.12 of AA freedom of movement for workers between Member States of the Community and Turkey shall be secured by progressive stages (...) between the end of the twelfth and the twenty-second year after the entry into force of that Agreement. In other words the aforementioned freedom was to be fully established by progressive stages between 1976 and 1986. Additionally, an Association Council was set up by the AA to control its development and give the agreement detailed effect by making binding decisions.

Given that AA introduced only rules of general nature, in 1970 the Communities and Turkey signed an Additional Protocol (Additional Protocol-AP) which contained more detailed provisions on rights of Turkish workers. However in the $70^{\prime}$ the political, economic and social climate proved unfamiliar for 
development of internal market, mostly due energy crisis. Thus EC Member States have taken advanced steps to stop further immigration from Turkey, which was generally caused by their decreasing economies and growing unemployment. Nevertheless a small improvement in the rights of existing Turkish migrant workers was observed, as the work of the Association Council was still continued. Consequently three successive acts were introduced, conferring additional rights on Turkish employees, namely Decisions 2/76, 1/80 and 3/80.

The provisions of AA and AP have not entered into force in the prescribed period due to several political and economic obstacles, but in 1987 Turkey applied to join the European Economic Community. Turkish government has made freedom of movement of the workers a part of its membership application, which was faced with growing German concern about the increasing number of Turkish immigrants. This has been an important factor both in the non-implementation of the freedom of movement provisions of AA/AP and finally in the non-acceptance of Turkey's membership application to the EU (Çiçekli, 2004). In the meantime the parties of the AA agreement focused on further negotiations, which resulted in Customs Union between Turkey and the EU. The customs union entered into force in 1997 and removed the barriers to freedom of movement of goods, but obviously not of workers, bringing an adverse effect on the full implementation and proper functioning of the Customs Union between Turkey and the EU (Çiçekli, 2004).

Three years later, at the Helsinki Summit, the European Council following the Commission's recommendation - offered Turkey the status of an official EU candidate state. Turkish involvement in European integration process was then confirmed through EU-Turkey Accession Partnership in 2001, which contained the detailed road map for Turkish accession; few months later the Turkish Government introduced the National Programme for the Adoption of the acquis (whole body of EU law). The Accession Negotiations opened in 2005, starting immediately with the screening process, but only one year later the European Union expressed concern over restrictions to the free movement of goods, including limitations on means of transport to which Turkey had committed by signing the Additional Protocol to the Ankara Agreement (Yalincak, 2013: 394). As a result negotiations on eight chapters relevant to Turkey's restrictions with regard to the Republic of Cyprus were suspended. The accession process have stalled with majority of acquis chapters frozen due to substantial reasons and issues emphasized by EU Member States, including collision of political, social, cultural, religious and policy considerations (Yalincak, 2013: 394).

On the one hand it can be presumed that Turkey's membership in the EU is only a matter of time; on the other it is not yet a foregone conclusion, because the negotiations do not lead automatically to accession. The shift however was made in 2013, when the General Affairs Council decided to open a new chapter in Turkey's accession negotiations. Now Ankara and Brussels will have a chance to make progress on 22nd chapter, devoted to regional policy (Bechev, 2013). As it will be 
presented in the next part of the paper, currently the both parties seem to be more focused on the visa dialogue, as its successful implementation may give a new impetus towards accession procedures.

For the reason of uncertain EU membership, the legal status of Turkish citizens crossing borders of the EU with the employment purposes and the scope of rights they enjoy depends on the content of the agreements concluded earlier with the Union. The position of such individuals is strictly related to EU-Turkish crossborder relations that belong to area combining immigration issues, freedoms of internal market and Schengen policy, where various legal regimes are involved. This forces more holistic research perspective - especially immigration context is becoming urgent in current shape of EU economy and there is no doubt that Europe is in need of labour force, which could be provided by Turkey as a country with high potential in human resources. The migration from Turkey to Europe started in the early 1960s, when the so-called "guest workers" were allowed to cross the borders of European Economic Community. As a result in 1963 almost 36,000 Turkish workers were employed in Germany, 5,600 in Belgium and 700 in the Netherlands (Groenendijk and Guild, 2010: 10).

The policy of family reunification pursued in the 1970s only increased the process of migration to Europe (Holscher, 2012: 6). The freedom of movement rights for Turkish nationals has been an important issue for Turkish citizens ever since 1980 when strict visa requirements were introduced. This problem still confronts all strata of Turkish society, including the business community, the academic world, students, journalists, and almost 4 million family members of Turkish nationals living in the EU (Yalincak, 2013: 392). Even though the public opinion in several EU member states tend to share serious fear of massive, uncontrolled inflow of Turkish cheap labour in case of liberalisation of visa policy, in fact Europe is nowadays confronted with back-migration of Turks, who - due to improving economic stability of their country of origin - often decide to return (Holscher, 2012: 24). Nevertheless immigration from Turkey, especially with reference to transit routes going through this country is considered a relevant political issue in EU-Turkey relations (Apap et al., 2004: 21).

It is widely accepted that there has been limited progress on the free movement of Turkish workers to the EU. This is despite of the legal instruments of Ankara Agreements and Additional Protocol that envisaged, as it was mentioned, the progressive stages of labour mobility by 1986 (Oğuz, 2012: 74). Given the fact that the holding of the nationality of a Member State is the condition sine qua non for acquiring citizenship of the EU, Turkish nationals clearly not hold it yet; however they can be described as "EU citizens in being". While the rights granted to Turkish nationals by the EU are amongst the most extensive granted to Third Country Nationals (TCNs), the outer limits of their freedom of movement rights are firmly rooted in the specific free movement provisions in EU-Turkey Association Law (Yalincak, 2013: 391). Leaving aside all the controversies related 
to Turkish accession to the EU and their potential impact on position of Turkish migrant workers, attention is given here to the full implementation of the binding acts constituting Turkey-EU Association Law.

\section{The Binding Force and Place of Association Law in the Framework of the Acquis Communautaire}

Generally, the free movement of the workers was intended as a set of rights limited to citizens of the member states of the EEC. Nowadays, according to provisions of the Treaties freedoms of internal market exist only in strict association with EU citizenship and - in principle - are not provided for TCNs. Nonetheless this regime has been often relaxed by various association agreements concluded by EEC and the EU, guaranteeing diverse scope of rights to workers from non-EU countries. Therefore Ankara Agreement with its components (which means Additional Protocol and Association Council's Decisions 1/80 and 3/80) still constitutes the primary source of rights and obligations for Turks engaged in economic activity as workers in the EU.

Undoubtedly these documents have put Turkish migrant workers in a more favourable position than most of the other TCNs, by creating a sort of intermediate legal regime applicable for Turkish immigrants across the EU. The developments under EU law within the context of Turkish-EU Association Law have proved to be the main source of progress as far as the legal integration of Turkish migrants is concerned (Çiçekli, 2004). However, implementation of free movement cannot be regarded self-executing, as the rules of achieving this freedom are to be decided in detail by Association Council. This was also confirmed by the Court of Justice of the EU, which in 1987 ruled in Demirel case that Article 36 of the AP in accordance with Article 12 of the AA governing the movement of the workers are not sufficiently precise and unconditional. As a matter of fact main provisions on legal integration of Turkish immigrants arriving for employment purposes have not been implemented, as they were not considered to be self-executing by CJEU (Demirel).

In general, the Ankara Agreement as well as the Protocol, which is integral part of it, is referred to as "mixed agreements", where not only Turkey and the Union, but also all Member States are parties to these agreements. According to the definition given by the CJEU in Demirel, an "association" creates "special, privileged links with a non-member country that must, at least to a certain extent, take part in the Community system (Polat, 2013: 156). It also means that the subject matter of the Association law remains partly within the scope of legal competence of the European Union (previously Communities) and partly of the Member States. Importantly, the CJEU has consequently ruled in successive judgements that the Association Law established between EU and Turkey constitutes a part of the Community legal order and that the provisions of these instruments are directly applicable in case they contain a clear, precise and unconditional obligation (Demirel; Sevince). 
According to the rulings of CJEU aforementioned agreements form an integral part of the acquis communautaire from their entry into force (Demirel); the Court also confirmed its jurisdiction to give preliminary rulings regarding the interpretation of Association law, including the provisions on freedom of movement for workers established in the Ankara Agreement and the Additional Protocol (Demirel, Sevince). It is worth noting, that similar line of interpretation was later applied in Yousfi case on the Cooperation Agreement with Morocco, and in Krid on the Cooperation Agreement with Algeria, where the relevant articles were held as conferring direct effect (Polat, 2013: 157). Additionally, the decisions of association councils (like one established on the basis of AA) may also be treated as agreements as they are both acts agreed between the Union and its Member States and third states with implications for the EU legal order, becoming this way a part of acquis communautaire.

\section{Secondary Law and Case Law Related with Free Movement of Turkish Workers}

The decisions 1/80 and 3/80 of Association Council are equal source of rights conferred upon Turkish workers and contain the most detailed provisions on their status in the EU (Peers, 1996: 8; Polat, 2013: 156). Efficient application of these regulations within the national law of the Member States has been secured by CJEU through its judicial activity devoted to interpretation of EU-Turkey Association Law. The most relevant principles governing the legal status of Turkish workers and granting them equal treatment may be defined as free access to the labour market of another Member State, the right to employment under the same conditions as nationals of the host state and eventually the right to remain in the territory of that state after the termination of employment. This includes significant rights related to social security of Turkish citizens legally employed on the territories of EU Member States - an issue which will be also covered in the following part of the paper.

The status of Turkish citizens concerning employment and free movement as established in Article 6 (1) of Association Council Decision 1/80, which outlines following rights conferred on Turkish worker duly registered as belonging to the labour force of a Member State:

1) A Turkish worker shall be entitled in a host Member State, after one year's legal employment, to the renewal of his permit to work for the same employer, if a job is still available;

2) He shall be entitled in that Member State, after three years of legal employment and subject to the priority given to workers of Member States of the Community, to respond to another offer of employment, with an employer of his choice, made under normal conditions and registered with the employment services of that Member State, for the same occupation; 
3) He shall enjoy free access in that Member State to any paid employment of his choice, after four years of legal employment.

Furthermore, the same principles referring to cross-border workers holding EU citizenship established by CJEU should be also applied to Turkish nationals. For example Turkish citizen employed on the basis of a part-time job will maintain its status of a worker (Levin). The status is even retained when received remuneration places below guaranteed minimum wage level or below the nationally recognised minimum subsistence level, unless the work is not considered genuine and does not constitute an economic activity (Levin). Generally, to be considered a worker, Turkish national must perform services for and under the direction of another person, in return for payment in cash or kind. The activities must be real and genuine, excluding small scale marginal activities. Under EU law, neither the nature of the employment relationship, the origin of the funds, nor the level of remuneration, matters. For instance following people are considered to be workers in the light of acquis (which refers obviously also to Turks): students working up to 10 hours a week in term time, trainees, apprentices, au pairs and those engaged in employment schemes.

The rights laid down for Turkish workers in Article 6 (1) are conditional upon being a worker, who is duly registered as belonging to the labour force of a host Member State, and period of legal employment. In Sevince the Court ruled, that the legality of employment must be determined in the light of the legislation of the receiving state governing the conditions under which the Turkish worker entered the national territory and is employed there (Çiçekli, 2004). The principle governing the system of rights of Turkish immigrant workers may be summarised as follows: the longer residence of employee, the more stabilised and secure status on the labour market he gains. The arrangement, according to CJEU allows for Turkish workers to gradually acquire more rights, thus leading to greater degree of integration in host Member State (Eker). It is also the national authorities, who are obliged to grant efficient execution of these rights - according to Article 6 (3) of Decision 1/80 all procedures necessary for applying rights of Turkish citizens conferred upon them in Article 6 (1) shall be established under national rules. This solution in fact leaves the no choice to national authorities weather as to put these fundamental rights into force and make them effective within Member State's legal order. In various judicial statements CJEU expressed the view, that rights provided for in this decision are directly effective (Kurz).

The access of Turkish citizens to the EU labour market (or more precisely territory and labour market of the host Member State) are among the most relevant topics that need to be discussed within the context of the decision 1/80. Despite the broad list of rights granted to Turkish immigrant workers, the Association law does not affect the Member States' competence to decide over the first entry into their territories of Turkish citizens and about the conditions under which they take up their first employment (Gunaydin). Additionally, it is clear that no right of free 
movement (initial admission) to the EU countries exists in relation to Turkish workers deriving from the association arrangements (Birden), unlike for migrant workers from EU Member States. The CJEU has consistently confirmed that individual Member States of the EU retain exclusive control over whether to admit an individual and under what terms into their respective territories (Çiçekli, 2004). Besides, in case of employment discontinuity the status of Turkish worker is again covered by provisions of legal order of host EU state, which offers definitely less privileged position. The right to residence in a host state as the one of fundamental right accorded to Turkish worker has been also examined by CJEU. First of all, such right does not exist as an independent rule and the Court explained the residence issue in Kus case, where position of Turkish worker residing in the EU Member State was clarified. According to the judicial statement, if the conditions of the art. 6 (1) of the Decision 1/80 have been met, the Turkish citizen has the right to obtain a residence permit in the host state (Kus).

The defined scope of rights also differs significantly from the one contained in Article 45 TFEU, as Association Law does not provide for a right to remain in a EU Member State after having been employed. This unfavourable position is to some extent balanced by Article 10 (1) of Decision 1/80, which stipulates, that once Turkish workers are duly registered as belonging to the labour market of the host state, they enjoy equal treatment with EU workers (persons holding EU citizenship) in respect of remuneration and other conditions of work. Non-discrimination on the grounds of nationality is undoubtedly one of the main principles of EU legal order. Accordingly, the right to equal treatment of Turkish employees seems to be fairly established in the Association Law, being also confirmed by Article 9 of AA, Article 37 of Additional Protocol and several decisions of the CJEU. Due to the content of special provisions mentioned above, Turkish immigrant workers are subject to the same obligations and enjoy the same benefits under the regulations of the host Member State on the same conditions as the nationals of state concerned. The meaning of non-discrimination clause is weakened however, since the scope of its application is limited to Turkish citizens legally employed in host Member State, and this approach reflects the fact that Turkish workers do not have an unconditional right to access the EU labour market. Article 7 of the Decision 1/80 covers the basic rights of the family members of Turkish immigrant workers. General rule stipulates that definition of family members belongs to the legal order of the receiving Member State, however CJEU has explained, that the term covers a spouse and children and even an unmarried partner (Kadiman, Akman, Eyup). Under the established rules persons mentioned above are entitled inter alia:

1) to respond to any offer of employment after they have been legally resident for at least three years in that Member State; 2) to enjoy free access to any paid employment of their choice provided they have been legally resident there for at least five years. 
It should be noted, that children of Turkish workers who have completed a course of vocational training in the host country may respond to any offer of employment there, irrespective of the length of time they have been resident in that Member State, provided one of their parents has been legally employed in the Member State concerned for at least three years (art.7). The derived rights of family members are based on the relationship with a beneficiary of direct rights (Turkish worker). In Kadiman and Derin CJEU interpreted these provisions as aiming to create conditions conducive to family unity by enabling family members to be with a migrant worker and then by consolidating their position by granting them the right to obtain employment in the host state and a concomitant right of residence (Yalincak, 2013: 24). The Court outlined however in other cases (Ergat) the legal status of these family members and concerning access to employment market for such persons that Article 7 only gives rights if a family member stays with the person he/she was authorised to join Turkish workers during the first three years, unless there is an objective reason such as work or education to live apart; after that the family member has independent rights (Barrett, 2003: 416; Polat, 2013: 161).

One of the most relevant issues related to Decision 1/80 is standstill clause established in art.13, providing that The Member States of the Community and Turkey may not introduce new restrictions on the conditions of access to employment applicable to workers and members of their families legally resident and employed in their respective territories. According to the Court, these provisions contain an unequivocal "standstill" clause regarding the introduction of new restrictions on access to the employment of workers legally resident and employed in the territory of the contracting States. In addition, the purpose and nature of decision 1/80 and the AA indicate their direct effect (Savas).

This interpretation was confirmed in various judicial statements, where the Court emphasised that the provisions of association law lay down clearly, precisely and unconditionally unequivocal standstill clauses, which contain an obligation entered into by the contracting parties which amounts in law to a duty not to act (Abatay). Thus, Article 13 of Decision 1/80 may be relied on by Turkish nationals in the Member State concerned to prevent the application of inconsistent rules prohibiting the introduction of new restrictions on the freedom of movement for workers (Çiçekli, 2004). Therefore it prevents Member States from applying to Turkish nationals legally present on their territory less favourable treatment as regards access to first employment than that applicable at the time of the entry into force of Decision 1/80 (Çiçekli, 2004). This may be of great importance for both Turkish workers and the members of their family, as it is illustrated by one of the recent rulings of CJEU in case of Dogan, where the court ruled against Germany's language requirement for Turkish spouses applying for residence in the country, rebuffing the German government and claiming that language requirement violates the standstill provision in the EU's association agreement with Turkey (Euractiv, 2014). However Article 13 will not give any substantive right as regards first 
admission, freedom of movement for workers or residence. In addition, given that these standstill clauses require Turkish workers to be legally resident and employed, the Member States remain de facto free to impose new restrictions with regard to the first admission of Turkish workers into their territory (Göçmen, 2009: 173).

It should be also mentioned, that interpretation of a standstill clause on freedom of establishment and to provide services has also been a matter of dispute, however findings of the CJEU with relation to these two freedoms were somewhat different. Currently the Court has a well settled case-law (Tum and Dari, Soysal, Oguz, Dereci) on the point that a Member State shall not subject a Turkish national to freedom of establishment and to provide services on the territory of that Member State to stricter conditions other than those which applied at the time when the Additional Protocol entered into force with regard to the Member State concerned (İçduygu et.al, 2013: 13). However a more recent debate came up with the Demirkan case, where a Turkish citizen argued that the standstill clause could be invoked not only by those wishing to provide services themselves ("active" freedom to provide services) but also by those wishing to receive services ("passive" freedom to provide services) (İçduygu et.al, 2013: 13). This would mean, that de facto all Turkish citizens (for instance as tourists - so in the view of EU law persons enjoying passive freedom of services) would be able to enter territories of the EU Member States without visa. However such a broad interpretation of "freedom to provide services" under the European Union Treaties was rejected and CJEU took eventually the view that the standstill clause does not apply in respect of the passive freedom to provide services (Demirkan).

The Association Law also refers to social rights of Turkish workers residing in the Member States and their family members. The rules on that matter are mainly included in decision 3/80. On this basis they enjoy similar rights to those accorded to citizens of the EU Member States. One of the principal goals of the Association Law was to coordinate Member States security systems in order to allow Turkish workers and members of their families to enjoy traditional social privileges - art. 39 of the AP stipulated that the Association Council shall adopt social security measures for workers of Turkish nationality, moving within the Community", as well as for their families residing in the Community (Çiçekli, 2004). Additionally, the Decision 3/80 establishes a principle of equal treatment and provides for equal treatment and coordination, however its scope is limited to workers, thus excluding self-employed (Polat, 2013: 162). The status of the Turkish worker is also weakened on the basis of the second paragraph of the art. 29 of AP, which envisages that periods of insurance or employment completed in individual Member States (but not in Turkey) in respect of old-age pensions, death benefits and invalidity pensions, and also as regards the provision of health services for workers and their families residing in the Community, shall be aggregated. Thus the aim of Article 39 (2) is to aggregate the periods of social security insurance cover acquired by a Turkish worker in more than one EU 
country, and excluding periods spent in Turkey (Çiçekli, 2004). The direct effect of the provisions of the Decision 3/80 was also confirmed by the CJEU (Taflan-Met).

\section{EU VISA POLICY TOWARDS TURKEY}

As it has been stipulated, the Association Law defines the conditions of access of the Turkish seeking employment on the territories of EU Member States, but does not confer the right of free movement or free admission to internal market. This distinguishes such workers from citizens of the EU, who enjoy unlimited right of entry to the territory of the host member state. The issue was also explained in various cases solved by CJEU, particularly in Tum and Dari, where the Court held that entry into a Member State is governed by the national laws of Member States, since no such positive right can be derived from the currently applicable EU law. This is to say that the main principle regarding first admission of Turkish citizens to a Member States is that these states are free to control the first access of Turkish nationals to their territory. However, Member States are no longer free once Turkish workers and their family members are legally resident in a Member State, because it is Decision 1/80 of the EEC-Turkey Association Council which governs their position (Tezcan-Idriz and Slot, 2010: 4).

It is worth noting - even if it goes beyond the scope of this paper - that in the same case the Court excluded application of the mentioned principle to the first admission of Turkish nationals wishing to establish a business or provide a service on the territory of a Member State of the Union (Tezcan-Idriz and Slot, 2010: 4). Since one can speak of rights of residence and continued employment only when a Turkish worker is already lawfully present and employed in EU Member State, the issues regarding the EU-Turkey visa relations should be also taken into consideration, as they significantly affect the right of entry to the EU and finally acquiring the status of the worker (Çiçekli, 2004).

There is no accident that the free movement of the workers has become a particularly relevant issue for Turkish citizens since 1980, when strict visa requirements were introduced by various Community States (Groenendijk and Guild, 2010: 11). In 1980 Germany introduced visa requirement for Turkish citizens in reaction to the significant increase of the number of asylum seekers from Turkey and soon other Member States followed the pattern, placing Turkey on a list of countries whose nationals need a visa for a short stay in EU Member States. Such policy towards Turkey was also agreed on community level in 1987, when the list was for the first time adopted at the meeting of the immigration ministers of the Member States in Copenhagen on 11 December 1987 (Groenendijk and Guild, 2010: 41). Today Turkey remains the only EU candidate country whose citizens are obliged to obtain a Schengen visa before being allowed to enter the EU. This is a source of intense frustration for Turkish citizens and government officials alike (Stiglmayer, 2012: 1). From Turkish perspective visa requirement is in contravention of Turkey-EU Association Law to the cumbersome and 
humiliating procedures, such as the amount of fee requested, number and nature of documents that need to be submitted, lack of facilities to host applicants at the consulates, and disrespectful treatment by consular staff (Özsöz, 2013: 1). Thus Turkish workers trying to enter a territory of the one of the Schengen countries must apply for a visa in compliance to the currently binding rules introduced by the Union. EU member states (with the exception of Ireland and the UK) have established a common visa policy, which constitutes one of the main parts of the Schengen System.

The EU policy is applied mostly through issuance of the so-called "Schengen visas", which are valid for short stays (up to 90 days). Citizens from some non-EU countries (like Turkey) are required to obtain the document before entering Schengen Area. The EU has additionally introduced a common (the "negative" or less formally - "black") list of countries whose citizens must acquire such permission when crossing the EU external borders, which is set out in Council Regulation 539/2001. The successive amendments of the Regulation are issued by Commission every year, with Turkey being constantly included on the black list. The short-stay (or Schengen) visas are not issued by any EU institutions responsible for management of common visa policy - the Schengen states are the ones to issue the document. Generally, a short-stay visa delivered by one of the Schengen States entitles its holder to travel throughout the Schengen area for up to 90 days in any 180-day period. At the core of the common visa policy remains the EU Visa Code (Regulation no. 810/2009) which outlines the conditions and procedures for issuing short-term visas and airport transit.

While issues concerning the short term visas are decided on the EU level (even though the documents are in fact issued by national entities), long-term visas (for stays in the Schengen Area which exceed 3 months) remain an exclusive national competence. Thus long-term visas issued for Turkish labour are national visas and are delivered by the EU Member States, but they shall be produced in the form of a uniform format (sticker). The documents entitle the holder to enter the Schengen Area and remain in the issuing state for maximum one year. A permission for a Turkish and other TCN's to remain in the territory of Schengen state for more than 12 months must be exchanged into residence permit. As Baysan has summarized, Schengen is a bunch of countries which share a common visa sticker, but which follow their own national visa policies. Moreover, even though the EU introduced various formal instruments with the aim to create harmonised single visa policy, the visa issuing process has suffered a great deal from discretionary practices (Baysan, 2013: 1).

Visa reciprocity with non-EU countries whose citizens are exempt from the visa requirement another pillar of unified policy. This guarantees that EU citizens would not need a visa either for travelling to these non-EU countries. In case of EU-Turkish relations on this complex issue, Turkey's visa policy towards nationals of EU Member States - compared to the application process to obtain a Schengen 
visa - though liberal, is far from being unified or even harmonised (Özsöz, 2013: 2). In fact nationals of EU Member States are subject to the two different types of procedures: the ones who are exempted from the visa requirement and the ones who require to have visa to enter Turkey. For example: while citizens of Denmark, the Czech Republic, Estonia or France are exempted from visa requirement for their travels to Turkey, nationals of Ireland, Belgium and Austria are required to obtain the visa to enter Turkey. Even though such document is easy to acquire, as electronic visa (e-Visa) replaced "sticker visa" issued previously at the border crossings, it should be highlighted that e-Visa is only valid when the purpose of travel is tourism or commerce. Other purposes, such as work and study, require a regular visa given by Embassies or Consulates (www.mfa.gov.tr, 01.12.2014).

Referring to EU visa policy it should be also noted, that decisions related to common visa system, including visa-free movement of persons may result from bilateral agreements between EU and non-EU countries. The visa facilitation agreements are based on the progress made by these states in implementing reforms in most relevant areas, such as the strengthening of the rule of law, combating of organised crime, corruption and illegal migration and improving of administrative capacity in border control and security of documents. In fact this process requires a country to carry out transformations that help protect the EU's external borders; in return, the visa requirement is lifted (Stiglmayer, 2012: 1). The so called visa-roadmaps established by contracting parties define all the stages and details of reforms undertaken by the country in question in order to meet the requirements of visa-free movement with the EU Member States. Additionally, since a decade the EU tends to conclude visa facilitation agreements together with readmission agreements, which set out clear obligations and procedures for the authorities of the non-EU country and of EU States as to when and how to take back immigrants who are irregularly residing in the EU (European Commission, EU visa policy 2014). Summarizing all up, these agreements required third countries to adopt reforms in line with the EU acquis governing border control and migration, as well as to agree to take back their own nationals who are illegally present in the Schengen Area together with illegal migrants who may have entered the EU having transited these countries. In return and as additional incentives, the EU promises 'mobility partnership', visa facilitation and in particular cases visa liberalisation for the nationals of these countries (Kirişci, 2014: 2).

Despite the successful visa liberalization process conducted with the Western Balkan countries in 2008 (Serbia, Bosna-Hercegovina, Albania, Macedonia and Montenegro) and more recently with Moldova and Ukraine (2013) EU constantly refused to establish visa-free regime with reference to Turkey, which means that obstacles for free movement of Turkish labour still remain. The reason for that is not only of political nature - it should be known that the relationship between the EU and Turkey with reference to free movement of persons is much more complicated than that of the Union and any other candidate or potential candidate country. With its current population around 73 million 
Turkey appears to European society as a source of possible migration inflows that may damage the EU future economic and cultural consistency. However economic indicators presented by Eurostat show that the Turkish economy experienced a dramatic transformation - in 2003, according to Eurostat, Turkey's per capita GDP was $36 \%$ of the EU average; by 2012 , this had increased to $54 \%$, positioning the country considerably ahead of the Western Balkan countries that had received visa liberalisation and the Central and East European countries that joined the EU in 2007. It should be highlighted, that at the same time, the number of Turkish nationals migrating to the EU dropped significantly compared to the 1980s and 1990s, stabilising between 50,000 and 60,000 (Kirişci, 2014: 3). Additionally a number of studies pursued in order to assess emigration intentions reports that 'only 0.3 (percent) of the population of Turkey has a specific intention to migrate, confirming that net migration between Turkey and the EU is negative (İçduygu and Karaçay, 2012; Baysan, 2013).

Together with constantly ageing population of Western Europe in mind, the formal obstacles for Turkish labour find no explanation. From a rationalist perspective, one would expect states to be in favour of dropping visa-restrictions for Turkey if expected benefits outweighed the potential costs of visa liberalisation (Baysan, 2013: 742). Furthermore, due to demographic and economic factors Europe will demand future labour from different kind of skills, and it seems like it will be not able to supply this demand from domestic labour markets. Some experts argue that even Turkey's accession will not be enough in the long run because of its rapid economic growth (Castles, 2006: 26; Aktas, 2010: 47). Since EU is experiencing a growing shortage of highly-qualified workers in various fields, the Blue Card Directive in 2009 was adopted. This solution was generally devised as a measure aimed at facilitating the entry of highly skilled migrants into the Union, with a view to counteract the EU's future lack of labour and skills through the increased entry of skilled workers from outside its borders (Cesarz, 2013: 240). The EU Blue Card Directive constitutes the first harmonizing instrument in the area of highly-skilled recruitment and employment on the European level which may also be used to stimulate mobility of Turkish workers for the benefit of the EU. Even though Europe is suffering from labour shortages, free movement of persons between Turkey and EU would demand solving another problem. During last few years Turkey has become a main destination country for asylum-seekers and immigrants from countries like Afgahistan, Pakistan, Somalia, Bangladesh, Uganda and particularly - Syria. Additionally the leaky Greek-Turkish border makes Turkey the main gate to EU countries used by illegal immigrants. This remains a challenge for both sides, affecting the foreign relations and preventing EU from lifting the visa obligations for Turkish citizens.

The new impetus towards relaxing the current regime may be given by a long-awaited readmission agreement accompanied by a roadmap for the liberalisation of visas for Turkish nationals, signed in December 2013 by the Home Affairs Commissioner Cecilia Malmström and the Turkish Minister of Foreign 
Affairs Ahmet Davutoğlu (Kirişci, 2014: 1-2). The deal foresees an arrangement where Turkey would accept to take back TCN's who have entered the EU illegally having transited through Turkey. In return, Turkey would receive support for reforming and revamping its border security and, much more importantly, Turkish nationals would be granted the right to travel in the Schengen Area visa-free (Kirişci, 2014: 1-2). The final establishment of visa-free regime between Turkey and EU is estimated to come into reality in 2017, but EU officials carefully avoid clear statements on that matter. It is more understandable in the context of the wording of the agreement, which stipulates that the pace of movement towards visa liberalisation will depend on Turkey's progress in adopting and implementing the measures and fulfilling the requirements set out in the visa roadmap, including full and effective implementation of the readmission agreement and effective cooperation vis-à-vis all EU Member States on Justice and Home Affairs (www.mfa.gov.tr, 01.12.2014). It should be also noted that even if all the requirements set out in the roadmap will be fully met, the Commission will be obliged only to present a proposal to the European Parliament and the Council to lift the visa obligation for Turkish citizens via an amendment of Council Regulation (EC 539/2001) (www.mfa.gov.tr, 01.12.2014). In view of increased representation of right-winged parties in the European Parliament and the negative attitude of big EU countries, especially France and Germany with respect to the liberalization of the EU visa policy towards Turkey, pushing through amendments to the Regulation 539/2001 should not be taken for granted.

\section{CONCLUSION}

The Union agreements confer on nationals of some states rights that the TCN's in general do not posses. This is to say there are some nationalities that are considerably better off relating to their legal status, including social security. Referring to typology established by Burrows, three categories of right holders in respect of employment may be outlined. While first category comprises essentially EU citizens, as individuals enjoying full spectrum of rights on the internal market, the last category refers to typical status of TCN's. As Burrows and Polat have concluded, Turkish workers form an "intermediate category", placed in between the nationals of EU and the citizens of other non-EU countries (Burrows, 1994: 307; Polat, 2013: 157). Obviously, they do not have the full range of rights of EU nationals, for example - Turkish workers still lack the right to move freely between the EU Member States, but neither can they be treated in the same way as other TCN's. It is abundantly clear that the fear of a massive inflow of labour from Turkey to the EU continues to be influential within this context, but the statistics, especially the ones indicating the rapid growth of Turkish economy do not provide any rational base for that.

The analysis of the rights conferred upon the Turkish workers in the context of current political trends and common visa policy raises doubts as to 
whether these rights may be fully exercised. Furthermore, the main provisions on legal integration of Turkish immigrants arriving for employment purposes have not been implemented, as they were not considered to be self-executing by Court of Justice of the EU. EU visa regulations and diversed national immigration policy practiced by EU Member States constitute an obstacle effectively discouraging the Turks to seek for a job in the Schengen area, only increasing the labour shortages in Europe. The situation may drastically change in the forthcoming years, if the dialogue between the European Commission and Turkish authorities in view of preparing, fostering and monitoring the visa liberalisation process will be successfully pursued. However the pace of movement towards visa liberalisation will depend on Turkey's progress in implementing reforms in order to meet the requirements of union acquis, thus putting a heavy financial and administrative burden on Turkey in exchange for the vague promise of an eventual visa facilitation (www.mfa.gov.tr, 01.12.2014). The potential delay in implementation of the visa roadmap will additionally affect the access of Turkish workers to the EU labour market.

\section{REFERENCES}

Additional Protocol and Financial Protocol annexed to the Agreement establishing the Association between the European Economic Community and Turkey and on measures to be taken for their entry into force, signed on 23 November 1970 (Brussels), entered into force on 1 January 1973, http://eurlex.europa.eu/LexUriServ/LexUriServ.do?uri=CELEX:21970A1123(01):EN:NOT

Agreement establishing an Association between the European Economic Community and Turkey, signed on 12 September 1963 (Ankara), entered into force on 1 December 1964, http://eur-lex.europa.eu/LexUriServ/LexUriServ.do?uri $=$ CELEX:21964A1229(01):EN:NOT

Aktas, M. (2010). What are the politics of labour mobility between turkey and the EU and to what extent do IR theories explain this politics. Unpublished Master Thesis. University of Twente, School of Management and Governence, Enschede.

Apap, J., Carrera, S. and Kirişci, K. (2004). Turkey in the EU Area of Freedom, Security and Justice. CEPS EU-Turkey Working Papers No. 3.

Barrett, G. (2003). Family matters: European Community law and thirdcountry family members. Common Market Law Review, 40 (2): 369-421.

Baysan, A. (2013). Multiple arenas and diverse techniques of securitisation: The case of the EU's Visa Regime towards Turkey. Journal of Contemporary European Research, 9 (5): 740-758. 
Bechev, D. (2013, 22 ${ }^{\text {nd }}$ October). A breath of fresh air in EU-Turkey accession talks. http://www.ecfr.eu/blog/entry/a_breath_of_fresh_air_in_eu_turkey _accession_talks, (10.10.2014).

Castles, S. (2006). Back to the future? Can Europe meet its labour needs through temporary migration? International Migration Institute, Working Paper No. 1.

Cesarz, M. (2013). The European Union's Blue Card System - Legal foundations, principles and controversies. J. Dyduch, M. Michalewska-Pawlak, and R. Murphy (Eds.) European Union development. Challenges and strategies: In 239-257. Warszawa: Aspra.

Council Regulation (EC) No. 539/2001 of 15 March 2001 listing the third countries whose nationals must be in possession of visas when crossing the external borders and those whose nationals are exempt from that requirement, [21.03.2001], OJ L81, http://eur-lex.europa.eu/LexUriServ/LexUriServ.do?uri= CONSLEG:2001R0539:20110111:EN:PDF

Çiçekli, B. (2004). "Legal Integration of Turkish Immigrants under the Turkish-EU Association Law". The Journal of Turkish Weekly, 2 November 2004. http://www.turkishweekly.net/2004/11/02/article/legal-integration-of-turkish-im migrants-under-the-turkish-eu-association-law/, (08.04.2014).

Euractive (2014). "European Court of Justice bans German language requirement for Turkish spouse visas". http://www.euractiv.com/sections/globaleurope/european-court-justice-bans-german-language-requirement-turkish-spousevisas, (11.10.2014).

Göçmen, I. (2009). Started to shine, but how brightly? Standstill provisions in Association Law between Turkey and the Community. Croatian Yearbook of European Law \& Policy, 5: 151-193.

Groenendijk, C. A. and Guild, E. (2010). Visa policy of Member States and the EU towards Turkish nationals after Soysal. Economic Development Foundation Publications, No. 232.

Holscher, L. C. (2012). Cross-border relations between Turkey and the European Union-An analysis of the freedom of services for Turkish Nationals. Unpublished Bachelor Thesis. University of Twente, School of Management and Governence, Enschede.

İçduygu, A., Göker, G. Z., Tokuzlu, L. B. and Elitok S. P. (2013). MPCMigration profile: Turkey. European University Institute, Migration Policy Centre Publication.

İçduygu, A. and Karaçay, A. B. (2012). Demography and migration in transition: Reflections on EU-Turkey relations. S. P. Elitok, T. Straubhaar (Eds.) 
Turkey, Migration and the EU: Potentials, Challenges and Opportunities: In 1938. Hamburg: Hamburg University Press.

Kirişci, K. (2014, $4^{\text {th }}$ February). Will the readmission agreement bring the EU and Turkey together or pull them apart? CEPS Commentary, http://www.ceps. eu/system/files/KK\%20EU-Turkey\%20readmission\%20agreement.pdf, (03.11.2014).

Oğuz, G. (2012). The Charter of Fundamental Rights of the European Union and Turkish Labour Migration. International Journal of Economic \& Administrative Studies, 4 (8): 151-157.

Özsöz, M. (2013). Turkey's Visa Policy towards nationals of EU Member States: A scenario of Visa-Free travel for all EU nationals to Turkey. Economic Development Foundation (IKV) Research Report.

Peers, S. (1996). Towards equality. Actual and potential rights of thirdcountry nationals in the European Union. Common Market Law Review, 33 (1): 7 50 .

Polat, C. (2013). Effects of Ankara Agreement within the Community Legal Order. Çalışma İlişkileri Dergisi, 1 (1): 151-171.

Regulation (EC) No. 810/2009 of the European Parliament and of the Council of 13 July 2009 establishing a Community Code on Visas (Visa Code), [15.09.2009] OJ L243, http://eur-lex.europa.eu/LexUriServ/LexUriServ.do?uri $=$ OJ:L:2009:243:0001:0058:en:PDF (01.12.2014).

Stiglmayer, A. (2012). Visa-Free Travel for Turkey: in Everybody's Interest. Turkish Policy Quarterly, 11 (1): 99-109.

Tezcan-Idriz, N. and Slot, P. J. (2010). Free Movement of Persons Between Turkey and the EU: the Hidden Potential of Article 41 (1) of the Additional Protocol. Centre for Law of EU External Relations Working Paper 2: 1-19.

Yalincak, O. H. (2013). Freedom of Movement Rights of Turkish Nationals in the European Union. Columbia Journal of European Law, 19 (3): 391 422.

\section{Case law}

Case 53/81 Levin v Staatssecretaris van Justitie [1982] ECR 1035. 03719.

Case C 12/86 Meryem Demirel v Stadt Schwäbisch Gmünd [1987] ECR

Case C-192/89 Sevince v Staatssecretaris van Justitie [1990] ECR. I-3461.

Case C 237/91 Kuş v Landeshauptstadt Wiesbaden [1992] ECR I-06781. 
Case C-103/94 Krid [1995] ECR I-719.

Case C 277/94 Taflan-Met v. Bestuur van de Sociale Verzekeringsbank [1996] ECR I-04085.

Case C-58/93 Yousfi [1994] ECR I- 1353.

Case C-351/95 Selma Kadıman v. Freistaat Bayern [1997] ECR I-2133.

Case C-386/95 Eker v. Land Baden-Württenberg [1997] ECR I-2697.

Case C-36/96 Faik Günaydın and Others v. Freistaat Bayern [1997] ECR I-5143.

Case C-210/97 Akman [1998] ECR I-7519.

Case 1/97 Mehmet Birden v. Stadtgemeinde Bremen [1998] ECR I-7747.

Case 329/97 Sezgin Ergat v. Stadt Ulm. [2000] ECR I-1487.

Case C-37/98 The Queen, ex parte: Abdul Nasir Savas v. Secretary of State for the Home Department [2000] ECR I-2927.

Case C-65/98 Safet Eyüp v. Landesgeschäftsstelle des Arbeitsmarktservice Vorarlberg [2000] ECR I-4747.

Case C-37/98 The Queen $v$ Secretary of State for the Home Department, ex parte Abdulnasir Savas [2000] ECR I-2927. ECR I- 10691.

Case 188/00 Bülent Kurz, né Yüce v. Land Baden-Württemberg [2002]

Case 317/01 and Case 369/01 Eran Abatay and Others v. Bundesanstalt für Arbeit (C 317/01) ECR I-12301. I-6181.

Case C-325/05 Ísmail Derin v. Landkreis Darmstadt-Dieburg [2005] ECR

Case C-16/05 Veli Tüm ve Mehmet Darl v Secretary of State for the Home Department [2007] ECR I-7415.

Case C 228/06 Mehmet Soysal and Ibrahim Savatl v Bundesrepublik Deutschland [2009] ECR I-01031.

Case C-256/11 Dereci and Others [2011] ECR I-0000.

Case C-186/10 Oguz [2011] ECR I-0000.

Case C-221/11 Leyla Ecem Demirkan [2013] ECR I-00000.

Case C-138/13 Naime Dogan v Bundesrepublik Deutschland [2014], (Unpublished). 